\title{
Pengaruh Model Pembelajaran Auditory, Intellectualy, Dan Repitition (Air) Terhadap Kemampuan Pemecahan Masalah Matematika Di Kelas Tinggi Sekolah Dasar
}

\author{
Yuni Yuliani ${ }^{1}$, Din Azwar Uswatun ${ }^{2}$, Astri Sutisnawati ${ }^{3}$ \\ 12)3)Program Studi Pendidikan Guru Sekolah Dasar; Universitas Muhammadiyah \\ Sukabumi; Sukabumi; yuni.yuliani91@gmail.com
}

\begin{abstract}
Abstrak._Penelitian ini bertujuan untuk menguji pengaruh dari model pembelajaran AIR terhadap kemampuan pemecahan masalah matematika siswa pada materi bangun datar di kelas IV Sekolah Dasar. Jenis penelitian ini berupa Quasi Experimental Design dengan desain Nonequivalent Control Group Design. Sampel penelitian ini yaitu kelas IV A dan kelas IV B SDN Cisaat Rambay Kabupaten Sukabumi. Pengumpulan data yang dilakukan dengan metode tes yang terdiri dari pretest dan posttest. Pembelajaran pada kelas eksperimen menggunakan model pembelajaran AIR sedangkan untuk kelas kontrol menggunakan pembelajaran langsung. Pembelajaran dilaksanakan sebanyak tiga kali pertemuan, baik dikelas eksperimen maupun kelas kontrol dengan materi yang sama yaitu bangun datar. Kedua kelas mempunyai kemampuan awal sama. Hasil perhitungan menunjukkan siswa dikelas eksperimen memiliki rata-rata hasil yang lebih tinggi dibandingkan dengan kelas kontrol. Rata-rata nilai akhir dari kelas eksperimen sebesar 78,33 sedangkan kelas kontrol sebesar 50,57. Adapun hasil perhitungan dari Uji $\mathrm{T}$ menunjukkan hasil signifikansi sebesar 0,000. Nilai sig. lebih kecil dari taraf signifikansi uji $(0,05)$. Artinya terdapat perbedaan hasil yang signifikan antara kelas eksperimen dan kelas kontrol. Berdasarkan hasil penelitian dapat disimpulkan bahwa model pembelajaran AIR memberi pengaruh terhadap kemampuan pemecahan masalah matematika siswa kelas IV SD pada materi bangun datar.
\end{abstract}

Kata Kunci: Kemampuan Pemecahan Masalah Matematika, Model Pembelajaran AIR, Bangun Datar.

Abstract. This study aims to examine the effect of the AIR learning model on students'
mathematical problem solving abilities in flat-woke material in grade IV of elementary
school. This type of research is in the form of Quasi Experimental Design with the
Nonequivalent Control Group Design. The sample of this research is class IV A and class IV
B SDN Cisaat Rambay, Kabupaten Sukabumi. Data collection was carried out by a test
method consisting of pretest and posttest. Learning in the experimental class uses the AIR
learning model while the control class uses direct learning. Learning is carried out three
times, both in the experimental class and in the control class with the same material, which is
to wake up flat. Both classes have the same initial ability. The calculation results show
students in the experimental class have higher average results compared to the control class.

Caruban : Jurnal Ilmiah Pendidikan Dasar 2(1), 11-23, 2019

p-ISSN 2615-1391, e-ISSN 2620-3219 @Prodi PGSD Universitas Swadaya Gunung Jati 
The average final grade of the experimental class is 78,33 while the control class is 50.57 . The results of the calculation of the T Test show the significance of 0,000. Sig value smaller test significance level (0.05). This means that there are significant differences in results between the experimental class and the control class. Based on the results of the study it can be concluded that the AIR learning model has an influence on the mathematical problem solving ability of elementary school students in elementary school fourth grade material.

Keywods: Mathematical Problem Solving Ability, AIR Learning Model, Two-Dimentional Shapes.

\section{Pendahuluan}

Matematika merupakan ilmu yang mempunyai peranan penting dalam menghasilkan sumber daya manusia yang berkualitas. Hal ini membuktikan bahwa matematika merupakan ilmu pengetahuan yang sangat penting untuk dikuasai, karena matematika merupakan ilmu yang berhubungan dengan penalaran dan pola pikir manusia. Selain itu interaksi manusia dalam kehidupan sehari-hari tidak terlepas dengan matematika.

Permendiknas Nomor 22 Tahun 2006 Depdiknas menjelaskan bahwa matematika perlu diberikan kepada siswa mulai dari jenjang pendidikan dasar untuk membekali peserta didik dengan kemampuan berpikir kritis, logis, analitis, kreatif, mengembangkan kemampuan kerjasama serta mengembangkan kemampuan komunikasi, ide, dan gagasan lain dengan menggunakan simbol, tabel, diagram dan media lainnya. Dengan demikian, matematika menjadi pelajaran yang wajib dipelajari dalam setiap jenjang pendidikan. Matematika penerapannya dibutuhkan oleh ilmu pengetahuan dan teknologi. Maka dari itu penguasaan ilmu matematika diperlukan dan dipahami dengan benar.

Penguasaan matematika diperlukan untuk membantu siswa dalam memecahkan masalah matematika dalam kehidupan sehari-hari. Sebagaimana yang dinyatakan oleh National Council of Teachers of Mathematics (NCTM) yang dikutip oleh Effendi (2012: 2), NCTM menetapkan lima standar kemampuan matematis yang harus dimiliki oleh siswa, yaitu: kemampuan pemecahan masalah, kemampuan komunikasi, kemampuan koneksi, kemampuan penalaran, dan kemampuan representasi. Kemudian menurut Posamentier dan Stepelmen, sebagaimana dikutip oleh Dewanti (2011: 36), NCSM (National Council of Science Museum) menempatkan 
pemecahan masalah sebagai urutan pertama dari 12 komponen matematika (Suwarman \& Candra, 2017: 152).

Pentingnya pemecahan masalah ditegaskan dalam NCTM (National Council of Teachers of Mathematics) (2000) bahwa pemecahan masalah merupakan bagian penting dalam pembelajaran matematika dan menjadi keterampilan matematis yang perlu dikuasai siswa. Kemampuan pemecahan masalah penting dimiliki siswa untuk mencapai hasil belajar yang optimal. Keterampilan tersebut termasuk pada berpikir matematika tingkat tinggi (high order mathematical thinking) yang harus dikembangkan dalam proses pembelajaran matematika (Fitri, 2016: 18).

Suherman (dalam Jannah \& Zuliana, 2015: 4) mendefinisikan pemecahan masalah merupakan bagian dari kurikulum matematika yang sangat penting dalam proses pembelajaran maupun penyelesaian, sehingga siswa dimungkinkan memperoleh pengalaman menggunakan pengetahuan serta keterampilan yang sudah dimiliki untuk diterapkan pada pemecahan masalah. Proses pemecahan masalah bukan sesuatu yang mudah karena proses pemecahan masalah melibatkan kemampuan tingkat tinggi, maka dari itu kemampuan pemecahan masalah harus dilatih dalam proses pembelajaran. Salah satu cara melatih kemampuan pemecahan masalah yaitu dengan cara penggunaan model pembelajaran dalam proses pembelajaran matematika. Model pembelajaran matematika sangat diperlukan terkait dengan pemahaman pemecahan masalah yang akan diperoleh oleh siswa, yang nantinya akan diaplikasikan ke dalam kehidupan sehari-hari.

Model pembelajaran sangat banyak, salah satunya yaitu model pembelajaran Auditory, Intelectual, Repitition (AIR). Lutfianasari (2017:4) menjelaskan bahwa: Model pembelajaran AIR adalah suatu model pembelajaran yang menekankan pada kegiatan belajar siswa, siswa secara aktif membangun sendiri pengetahuannnya secara pribadi maupun kelompok dengan cara menggunakan tiga unsur belajar.

Menurut Huda (2017: 289) mengungkapkan AIR merupakan model pembelajaran yang mirip dengan model pembelajaran SAVI, perbedaannya terletak pada pengulangan (Repitition) yang bermakna pendalaman, perluasaan dengan pemberian tugas atau kuis. Model pembelajaran yang 
melibatkan siswa secara aktif adalah model pembelajaran AIR (Auditory, Intellectualy, dan Repitition) (Martini, Tripalupi \& Haris, 2017: 4). Model pembelajaran AIR (Auditory, Intellectualy, dan Repitition) merupakan model pembelajaran yang menggunakan tiga unsur belajar yaitu auditory (kegiatan berbicara dan mendengarkan), Intellectualy (proses berpikir) dan Repetition (pengulangan) yang dilakukan secara individu berupa tugas sebagai stimulus dan respon dari guru terhadap siswa untuk mengulas kembali pembelajaran yang sudah dipelajari oleh siswa baik dalam diskusi maupun keseluruhan proses pembelajaran, dan sebagai bahan evaluasi bagi guru untuk melihat letak kesulitan siswa dan dapat merancang pembelajaran selanjutnya, agar ada interaksi guru dengan siswa melalui stimulus dan respon tersebut.

Melalui model tersebut dalam proses pembelajaran siswa dilatih untuk memanfaatkan potensi yang sudah dimilikinya sebagai modalitas belajar yakni auditory, dan Intellectualy kemudian ditambah repetition untuk memperkuat pemahaman dan daya ingat siswa. Menurut penelitian yang dilakukan Huda (dalam Suwarman \& Candra, 2017: 153) menyatakan bahwa salah satu pembelajaran yang aktif dan inovatif untuk pemecahan masalah adalah model pembelajaran Auditory, Intellectualy, Repetiton (AIR). Model pembelajaran efektif digunakan untuk pemecahan masalah jika memperhatikan tiga hal, yaitu Auditory, Intellectualy, dan Repetition (Suwarman \& Candra, 2017: 153). Model pembelajaran AIR merupakan model pembelajaran yang dapat menjadikan kegiatan belajar mengajar menjadi lebih kondusif dan menyenangkan (Misnawati, 2017: 78).

Model AIR terdapat kelebihan dan kekurangan. Salah satu kelebihannya yaitu siswa lebih berpartisipasi aktif dalam pembelajaran dan siswa memiliki banyak pengalaman untuk menemukan sesuatu dalam menjawab permasalahan.

Berdasarkan penjelasan-penjelasan tersebut peneliti sangat tertarik melakukan penelitian dengan mengujicobakan pengaruh model AIR terhadap kemampuan pemecahan masalah matematika siswa kelas tinggi di Sekolah Dasar. Sehingga peneliti akan mengungkapkan pengaruh model AIR terhadap kemampuan pemecahan masalah matematika siswa.

\section{Metode Penelitian}


Jenis penelitian yang digunakan dalam penelitian ini adalah jenis penelitian kuasi eksperimen (Quasi Experimental Design). Metode kuasi eksperimen adalah metode yang memiliki kelompok kontrol, tetapi tidak dapet berfungsi sepenuhnya untuk mengontrol variabel-variabel luar yang mempengaruhi pelaksanaan eksperimen (Sugiyono, 2015: 114). Peneliti dilakukan dengan membagi kelompok yang diteliti menjadi dua kelonpok, yaitu kelompok eksperimen yang mendapatkan perlakuan dengan menggunakan model pembelajaran AIR dalam proses pembelajraan matematika dan kelompok kedua adalah kelompok kontrol tidak menggunakan model AIR dalam proses pembelajaran matematika. Adapun desain penelitian eksperimen yang digunakan dalam penelitian ini adalah Nonequivalent Control Group Design. Pada desain ini kelompok eksperimen ataupun kelompok kontrol tidak dapat dipilih secara random (Sugiyono, 2015: 116).

Populasi penelitian ini yaitu seluruh siswa kelas IV SDN Cisaat Rambay Kabupate Sukabumi. Sampel yang digunakan pada penelitian ini yaitu sampling jenuh. Menurut Sugiyono (2015: 124) sapling jenuh adalah sampel yang digunakan dimana seluruh populasi digunakna sebagai sampel penelitian. Sampel pada penelitian ini terdiri dari 60 siswa yaitu 30 siswa dari kelas IV A dan 30 siswa dari kelas IV B.

Teknik pengumpulan data yang digunakan dalam penelitian ini adalah teknik tes. Tes yang digunakan dalam penelitian ini berupa Pretest (sebelum diberikan perlakuan) dan Posttest (setelah diberikan perlakuan). Soal diujicobakan dengan melakukan uji validitas, reliabilitas, tingkat kesukaran, dan daya pembeda. Hal tersebut dilakukan untuk mengetahui adanya pengaruh model pembelajaran AIR terhadap kemampuan pemecahana masalah matematika siswa.

Analisis uji prasyarat yang digunakan meliputi uji normalitas, uji homogenitas, uji T dua sampel independen, uji Paired Sampel T Test, dan uji hipotesisi menggunakan uji $\mathrm{T}$ dua sampel independen.

\section{Hasil Penelitan dan Pembahasan}

Penelitian ini dilaksanakan pada semester genap tahun ajaran 2018/2019 di SDN Cisaat Rambay Kabupaten Sukabumi. Penelitian ini dimulai pada tanggal 4 Maret 2019 sampai dengan 21 Maret 2019, sampel 
yang digunakan adalah sampling jenuh karena seluruh populasi dalam penelitian ini dijadikan sebagai sampel penelitian. Sampel berjumlah dua kelas, yaitu kelas IV A sebagai kelas kontrol yang berjumlah 30 orang dan kelas IV B sebagai kelas eksperimen yang berjumlah 30 orang. Pada proses pembelajarannya, kedua kelas tersebut mendapatkan perlakuan yang berbeda. Kelas eksperimen dilakukan pada kelas IV B dengan melaksanakan pembelajaran pada materi bangun datar dengan menggunakan model pembelajaran AIR, sedangkan kelas kontrol dilakukan pada kelas IV A dengan melaksanakan pembelajaran tanpa menggunakan model pembelajaran AIR.

Data nilai pretest kemudian dihitung menggunakna uji prasyarat, yaitu dihitung menggunakan uji normalitas dan uji homogenitas. Uji normalitas digunakan untuk mengetahui apakah data berasal dari populasi berdistribusi normal atau tidak. Sedangkan uji homogenitas digunakan untuk mengetahui apakah vairians data dari kedua sampel bervarians homogeny atau tidak. Hasil data pretest dari kelas eksperimen dan kelas kontrol diuji menggunakan uji $\mathrm{T}$ dua sampel independen untuk mengatahui apakah kelas eksperimen dan kelas kontrol memiliki kemmapuan awal yang sama sebelum dilaksanakan penelitian. Uji $\mathrm{T}$ dua sampel independen dilakukan dengan menggunakan bantuan aplikasi SPSS 16 dengan taraf signifikansi 0,05.

Tabel 1. Hasil Uji T Dua Sampel Independen Kemampuan Awal Siswa

\begin{tabular}{lllll}
\hline Sampel & Rata-Rata & $\begin{array}{l}\text { Nilai } \\
\text { tailed })\end{array}$ & $\begin{array}{c}\text { Sig. } \\
\mathrm{n}\end{array}$ \\
\hline Kelas & 47,23 & & Keputusa \\
eksperimen & & 0,895 & $\mathrm{H}_{0}$ \\
Kelas kontrol & 46,60 & & diterima \\
\multicolumn{2}{l}{ Sumber: Data Penelitian, 2019} & &
\end{tabular}

Berdasarkan Tabel 1. dapat dilihat bahwa hasil pengujian dari uji $\mathrm{T}$ dua sampel independen didapatkan nilai sig. 0,895. Karena nilai sig. > 0,05 maka $\mathrm{H}_{0}$ diterima dan $\mathrm{H}_{1}$ ditolak. Dapat disimpulkan bahwa kelas eksperimen dan kelas kontrol memiliki kemampuan awal yang sama. 
Sama halnya dengan data nilai posttest kemudian dihitung menggunakan uji prasyarat, yaitu dengan menggunakan uji normalitas dan uji homogenitas. Hasil pengujian normalitas untuk kelas eskperimen menggunakan uji Kolmogorov-Smirnov diperoleh nilai sig. $=0,042$ dan dengan menggunakan uji Shapiro-Wilk diperoleh nilai sig. $=0,010$. Karena kedua nilai sig. > 0,05 maka $\mathrm{H}_{0}$ diterima dan dapat disimpulkan bahwa kelas eksperimen berasal dari populasi yang berdistribusi normal. Sedangkan pada kelas kontrol pengujian normalitas dengan menggunakan uji Kolmogorov-Smirnov diperoleh nilai sig. $=0,086$ dan dengan menggunakan uji Shapiro-Wilk diperoleh nilai sig. $=0,043$. Karena kedua nilai sig. $>0,05$ maka $\mathrm{H}_{0}$ diterima dan dapat disimpulkan bahwa kelas kontrol berasal dari populasi ynag berdistribusi normal. Hasil pengujian homogenitas data hasil akhir siswa (posttest) diperoleh nilai sig. $=0,074$. Karena kedua nilai sig. $>0,05$ maka $\mathrm{H}_{0}$ dierima. Sehingga dapat disimpulkan bahwa data hasil kemampuan akhir siswa (posttest) kelas eksperimen dan kelas kontrol berasal dari populasi yang bervarians homogen. Untuk mengetahui perbedaan hasil sebelum dan sesudah diberikan perlakuan, maka di uji menggunakan Uji Paired-Samples $T$ Test. Hal tersebut dilakukan pada hasil posttest dan hasil pretest kelas eksperimen dan kelas kontrol.

Tabel 2. Hasil Uji Paired Sampel T Test

\begin{tabular}{lllll}
\hline Sampel & $\begin{array}{l}\text { Rata-rata } \\
\text { pretest }\end{array}$ & $\begin{array}{l}\text { Rata-rata } \\
\text { posttest }\end{array}$ & $\begin{array}{l}\text { Nilai sig. } \\
\text { tailed })\end{array}$ & $\begin{array}{l}\text { (2- Keputusa } \\
\mathrm{n}\end{array}$ \\
\hline $\begin{array}{l}\text { Kelas } \\
\text { eksperimen }\end{array}$ & 47,23 & 78,33 & 0,000 & $\mathrm{H}_{0}$ ditolak \\
Kelas kontrol & 46,60 & 50,57 & 0,365 & $\begin{array}{l}\mathrm{H}_{0} \\
\text { diterima }\end{array}$ \\
\hline
\end{tabular}

Sumber: Data Penelitian, 2019

Berdasarkan Tabel 2. dapat dilihat bahwa hasil pengujian dari uji Paired Samples T Test didapatkan nilai sig. $=0,000$ untuk kelas eksperimen. Karena nilai sig. $<0,05$ maka $\mathrm{H}_{0}$ ditolak dan $\mathrm{H}_{1}$ diterima. Sedangkan untuk kelas kontrol diperoleh nilai sig. $=0,365$ karena nilai sig. $>0,05$ maka $\mathrm{H}_{0}$ diterima dan $\mathrm{H}_{1}$ ditolak. Setelah dilakukan pengujian menggunakan uji Paired Samples $\mathrm{T}$ Test dpat dilihat bahwa perbedaan hasil posttest dan 
pretest untuk kelas eksperimen, sedangkan kelas kontrol tidak terdapat perbedaan antara pretest dan posttest.

Untuk menjawab rumusan masalh dalam penelitian ini yaitu dengan uji hipotesis menggunakan uji $\mathrm{T}$ dua sampel independen. Uji $\mathrm{T}$ dua sampel independen dilakukan dengan menggunakan SPSS 16 dengan taraf signifikansi 0,05. Kriteria uji yaitu $\mathrm{H}_{0}$ ditolak dan $\mathrm{H}_{1}$ diterima jika nilai sig. < 0,05 .

Tabel 3. Hasil Uji Hipotesis

\begin{tabular}{llll}
\hline Sampel & Rata - Rata & $\begin{array}{l}\text { Nilai sig. } \\
\text { tailed })\end{array}$ & (2- Keputusan \\
\hline $\begin{array}{l}\text { Kelas } \\
\text { eksperimen }\end{array}$ & 78,33 & 0,000 & Ho ditolak \\
Kelas kontrol & 50,57 & & \\
\hline
\end{tabular}

Sumber: Data Penelitian, 2019

Berdasarkan Tabel 3. dapat dilihat bahwa hasil uji hipotesis menggunakan uji $\mathrm{T}$ dua sampel independen didapatkan nilai sig. $=0,000$. Nilai sig. tersebut lebih kecil dari 0,05 sehingga dapat disimpulkan $\mathrm{H}_{0}$ ditolak dan $\mathrm{H}_{1}$ diterima. Artinya terdapat perbedaan yang signifikan antara kelas eksperimen dan kelas kontrol.

Berdasarkan hasil penelitian tersebut, terdapat beberapa faktor yang menyebabkan perbedaan hasil belajar antara kelas eksperimen dengan kelas kontrol, diantaranya adalah pada kelas eksperimen siswa diberikan perlakuan yaitu model pembelajaran AIR sedangkan kelas kontrol hanya menggunakan pembelajaran yang berpusat pada guru. Pada kelas eksperimen dalam proses pembelajarannya menggunakan model Auditory, Intellectualy Repitition (AIR) untuk mengetahui pengaruhnya terhadap kemampuan pemecahan masalah. Pemecehan masalah menurut Polya (1985) (dalam Roebyanto \& Harmini, 2017: 14) bahwa pemecahan masalah sebagai suatu cara menemukan jalan keluar dari suatu kesulitan untuk mencapai suatu tujuan yang tidak dapat segera dicapai, pemecahan masalah memiliki indikator, diantaranya yaitu menurut Nurmalasari (dalam Rostika dan Junita, 2017) mengidentifikasi unsur yang diketahui, yang ditanyakan dan kecukupan unsur yang diperlukan, merumuskan masalah matematika atau 
menyusun model matematikanya, menerapkan strategi penyelesaian berbagai masalah didalam atau diluar matematika, dan menjelaskan atau mengiterpretasikan hasil sesuai dengan pemahaman asal.

Pada indikator mengidentifikasi kecukupan unsur, siswa diminta untuk menuliskan infomarmasi apa saja yang diberikan dan ditanyakan kemudian menentukan kecukupan unsur-unsur yang diketahui, unsur yang terlibat dalam indikator ini yaitu unsur auditory dan intellectualy. Indikator membuat model matematika, pada indikator ini siswa diminta untuk menuliskan model matematika berdasarkan informasi yang diberikan dan ditanyakan yang akan mengarah kepada penyelesaian soal, unsur yang terlibat dalam indikator ini yaitu unsur intellectualy. Indikator memilih dan menerapkan strategi penyelesaian, pada indikator ini siswa diminta untuk dapat menentukan rumus, konsep atau aturan yang dapat digunakan untuk dapat menyelesaikan masalah kemudian menerapkan rumus, konsep atau aturan yang telah dipilih tersebut, unsur yang terlibat dalam indikator ini yaitu intellectualy. Indikator memeriksa dan menjelaskan hasil, pada indikator ini siswa diminta untuk memeriksa kebenaran dari suatu pernyataan yang terdapat pada soal kemudian menjelaskan hasilnya, unsur yang terlibat dalam indikator ini yaitu unsur intellectualy dan repetition.

Proses pembelajarannya, dengan menggunakan model AIR siswa memanfaatkan indera yang dimilikinya secara maksimal mulai dari indera telinga yang digunakan untuk mendengar penyampaian dari guru dan temannya, berbicara, dan menanggapi, kemudian menggunakan kemampuan berpikirnya untuk memecahkan suatu permasalahan yang diberikan serta dilanjutkan dengan latihan untuk memantapkan apa yang telah dipelajarinya sehingga akan meningkatkan kemampuan pemecahan masalah matematika. Tidak hanya itu model pembelajaran efektif digunakan untuk pemecahan masalah jika memperhatikan tiga hal, yaitu Auditory, Intellectualy, dan Repetition (Suwarman \& Candra, 2017: 153).

Model pembelajaran AIR merupakan model pembelajaran yang menekankan tiga aspek, yaitu auditory, intellectualy, dan repetition. Auditory bermakna bahwa belajar harus melalui mendengarkan, menyimak, berbicara, mengemukakan pendapat, dan menanggapi. Intellectualy bermakna belajar harus menggunakan kemampuan berpikir, harus dengan konsentrasi pikiran 
dan berlatih menggunakannya melalui bernalar, mengidentifikasi, memecahkan masalah dan menerapkan. Repetition artinya pengulangan, dengan tujuan memperdalam dan memperluas pemahaman siswa yang perlu dilatih melalui pengerjaan soal, pemberian tugas, dan kuis. Pengulangan dalam kegiatan pembeljaran dimaksudkan agar pemahaman siswa lebih mendalam (Shoimin, 2014). Dengan mengintegrasikan ketiga aspek tersebut, akan membuat siswa lebih aktif dalam proses pembelajaran untuk memahami materi dan konsep yang dipelajari, sehingga siswa tidak hanya sekedar menghafal yang nantinya membuat siswa menjadi cepat lupa terhadap konsep yang dipelajari. Model pembelajaran yang melibatkan siswa secara aktif adalah model pembelajaran AIR (Auditory, Intellectualy, dan Repitition) (Martini, Tripalupi \& Haris, 2017: 4).

Pelaksanan pembelajaran dengan model AIR ini diawali dengan tahap persiapan, tahap ini dilakukan pada saat pendahuluan dalam pembelajaran, dalam tahap ini guru membangun motivasi dna minat siswa dalam pembelajaran; tahap penyampaian, pada tahap ini siswa diberikan penjelasan materi/konsep oleh guru, unsur yang terlibat dalam tahap ini yaitu unsur auditory; tahap pelatihan, pada tahap ini siswa difasilitasi dalam aktifitas intelektual, seperti kegiatan berdiskusi, menyampaikan pendapatnya, sehingga unsur yang terlibat dalam tahap ini yaitu unsur auditory dan intellectually; tahap menyampaikan, pada tahap ini siswa menyampaikan pengetahuajn baru yang diperolehnya, siswa mengerjakan soal secara individu dengan berbatuan guru siswa dapat menyimpulkan hasil pembelajaran yang telah dilaksanakan, unsur yang terlibat dalam tahap ini yaitu unsur repetition Meier (dalam Misnawati, 2017).

Pembelajaran dengan menggunakan model AIR memiliki pemahaman yang lebih mendalam daripada siswa yang belajar tidak menggunakan model pembelajaran AIR. Selain memberikan kesempatan untuk mengembangkan kemampuan komunikasi dengan menggunakan model AIR, siswa juga diberikan kesempatan untuk mengembangkan kemampuan intelektualnya dengan jalan pemecahan masalah, menganalisis dan menghubungkan informasi yang telah diperoleh sebelumnya dengan permasalahn yang sedang dihadapi (Widiastuti, Suniasih \& Kristiantari, 2014). 
Berbeda dengan kelas kontrol yang belajar dengan berpusat pada guru. Pada pelaksanaannya di kelas kontrol yang menggunakan pembelajaran langsung siswa hanya berdiskusi dengan teman sebangkunya saja dan pembelajaran lebih berpusat kepada guru sehingga siswa pasif saat kegiatan pembelajaran. Siswa tidak diberikan LKS dan hanya diberikan soal latihan untuk melatih kemampuannya dalam memahami kemampuan pemecahan masalah dalam materi bangun datar. Sehingga siswa bosan, jenuh dalam proses pembelajaran sehingga minat belajar siswa menurun.

Berdasarkan uraian diatas, dapat disimpulkan bahwa model pembelajaran AIR dapat berpengaruh positif terhadap kemampuan pemecahan masalah siswa di Sekolah Dasar di kelas tinggi pada mata pelajaran matematika materi bangun datar. Hasil penelitian ini menguatkan pernyataan dari Huda (dalam Suwarman \& Candra, 2017: 153) menyatakan bahwa salah satu pembeljaran yang aktif dan inovatif untuk pemecahan masalah adalah model pembelajaran AIR.

\section{Simpulan Dan Rekomendasi}

Berdasarkan hasil penelitian yang dilakukan dapat ditarik kesimpulan bahwa siswa yang belajar dengan model pembelajaran AIR memiliki hasil belajar yang lebih tinggi dibandingkan dengan siswa yang belajar dengan pembelajaran langsung. Hasil rata-rata posttest kelas eksperimen lebih tinggi yaitu 78,33 dari pada nilai rata-rata yang diperoleh kelas kontrol yaitu 50,57. Selain itu hasil perhitungan dari Uji $\mathrm{T}$ menunjukkan hasil signifikansi sebesar 0,000. Nilai signifikansi tersebut lebih kecil dari taraf signifikansi uji $(0,05)$, artinya terdapat perbedaan hasil yang signifikan antara kelas eksperimen dan kelas kontrol. Maka dapat disimpulkan bahwa model pembelajaran AIR berpengaruh terhadap kemampuan pemecahan masalah matematika siswa pada materi bangun datar.

Adapun rekomendasi yang dapat disampaiakan berdasarkan hasil penelitian yang telah dilakukan yaitu yang pertama, model pembelajaran AIR memerlukan waktu yang cukup lama dalam pelaksanaannya pada proses pembelajaran. Maka sebaiknya dalam pembelajaran dilaksanakan dengan alokasi waktu yang panjang agar pembelajaran lebih efektif dan kondusif. Kedua, penggunaan model AIR perlu diterapkan oleh guru dalam 
pembelajaran matematika sebagai alternatif untuk meningkatkan kemampuan pemecahan masalah matematika. Dan ketiga, sebaiknya diadakan penelitian lebih lanjut mengenai penggunaan model pembeljaaran AIR dalam mata pelajaran matematika di Sekolah Dasar untuk membuktikan kebenaran bahwa model pembelajaran tersebut dapat berpengaruh positif terhadap kemampuan pemecahan masalah siswa Sekolah Dasar.

\section{Daftar Pustaka}

Depdiknas. (2006). Kurikulum Tingkat Satuan Pendidikan. Jakarta: Pusat Kurikulum, Balitbang Depdiknas.

Fitri, A. (2016). Penerapan Pendekatan Pemecahan Masalah Matematika dengan Media Presentasi untuk Meningkatkan Kemampuan Menyelesaikan Soal Cerita. Jurnal Sekolah Dasar. 1, (1)

Huda, M. (2017). Model-Model Pengajaran Dan Pembelajaran. Yogyakarta: Pustaka Pelajar.

Jannah \& Zuliana. (2015). Peningkatan Kemampuan Pemecahan Masalah Matematika Siswa Kelas IV SD 3 Tenggeles Melalui Model Pembelajaran Berbasis Masalah Materi Pecahan.

Lutfianasari, D. (2017). Pengaruh Model Pembeljaran Auditory, Intelectually, Repitition (AIR) Terhadap Hasil Belajar Matematika Materi Sistem Persamaan Linear Dua Variabel Siswa Kelas VIII UPTD SMPN 1 Semen Kabupaten Kediri Tahun Pelajaran 2016/2017. Skripsi FKIP Universitas Nusantara PGRI Kediri: tidak diterbitkan.

Martini, dkk. (2017). Pengaruh Model Pembelajaran Auditory, Intelectually, Repitition (AIR) Terhadap Hasil Belajar Siswa Pada Mata Pelajaran Ekonomi Kelas X IPS Di SMAN 3 Singaraja Tahun Pelajaran 2017/2018. ejournal Jurusan Pendidikan Ekonomi. 10, (2).

Misnawati, T. (2017). Meningkatkan Hasil Belajar dan Aktivitas Siswa Melalui Model Pembelajaran Auditory Intelectually Repetition (AIR) pada Materi Segi Empat Kelas VII SMPN 9 Haruai Tahun Pelajaran 2016/2017. Sagacious Jurnal Ilmiah Pendidikan Dan Sosial. 4, (1).

Suwarman, F., dan Candra, A. (2017). Pengaruh Model Pembelajaran Auditory, Intelectually and Repetition (AIR) terhadap Kemampuan Pemecahan Masalah, 6 (2). 
Roebyanto \& Harmini. (2017). Pemecahan Masalah Matematika. Bandung: PT Rosdakarya.

Rostika, D., \& Junita, H. (2017). Peningkatan Kemampuan Pemecahan Masalah Siswa SD dalam Pembelajaran Matematika dengan Model Diskursus Multy Representation (DMR). EduHumaniora: Jurnal Pendidikan Dasar. 9 (1).

Shoimin, A. (2014). 68 Model Pembelajaran Inovatif dalam Kurikulum 2013. Yogyakarta: AR-Ruzz Media.

Sugiyono. (2015). Metode Penelitian Pendidikan. Bandung: Alfabeta.

Widiastuti, Suniasih \& Kristiantari (2014). Pengaruh Model Auditory Intellectualy Repitition Berbantuan Tape Recorder Terhadap Keterampilan Berbicara. Jurnal Mimbar PGSD Universitas Pendidikan Ganesh 